Newfoundland and Labrador Studies

\title{
Donald Hustins. Rivers of Dreams: The Evolution of Fly-Fishing and Conservation of Atlantic Salmon in Newfoundland and Labrador (1700-1949).
}

\section{Jason Hall}

Volume 29, Number 1, Spring 2014

URI: https://id.erudit.org/iderudit/1062251ar

DOI: https://doi.org/10.7202/1062251ar

See table of contents

Publisher(s)

Faculty of Arts, Memorial University

ISSN

1719-1726 (print)

1715-1430 (digital)

Explore this journal

Cite this review

Hall, J. (2014). Review of [Donald Hustins. Rivers of Dreams: The Evolution of Fly-Fishing and Conservation of Atlantic Salmon in Newfoundland and Labrador (1700-1949).] Newfoundland and Labrador Studies, 29(1).

https://doi.org/10.7202/1062251ar viewed online.

https://apropos.erudit.org/en/users/policy-on-use/ 


\section{Reviews}

Donald Hustins. Rivers of Dreams: The Evolution of Fly-Fishing and Conservation of Atlantic Salmon in Newfoundland and Labrador (1700-1949). St. John's, 2010. ISBN 978-0-978224-51-6

Donald Hustins draws on his experience as a fly fisherman, conservationist, and civil servant to chronicle the development of the fly-fishing industry and Atlantic salmon conservation in Newfoundland and Labrador from 1700 to 1949. His work conveys the importance of fly-fishing and conservation to Newfoundland and Labrador's history and the significance of conservation to the survival of Atlantic salmon and the fishing industry. Hustins also explores the changing values of anglers and conservation workers across time and deepens readers' appreciation of the riparian geography of Newfoundland and Labrador.

Rivers of Dreams is a popular history that traces 250 years of struggle to develop effective conservation regulations and to raise public awareness of the need to protect Atlantic salmon from overfishing, pollution, obstructions, and habitat degradation. These conservation initiatives included enforcement of restrictions on British settlement and fishing on the French Shore, establishment of wardens, bans on netting, and the emergence of licensing systems and closed seasons. Hustins also explores debates over such matters as artificial fish propagation, leasing freshwater fishing rights to private clubs, and the construction of fishways to help salmon reach spawning grounds. His discussion of these issues includes fascinating glimpses of the history and character of Newfoundland and Labrador waterways as well as the habits and habitats of Atlantic salmon.

The book provides a rich history of the people who developed sport fishing and conservation in Newfoundland and Labrador. Rivers of Dreams uses letters, reports, memoirs, newspapers, and magazines to illuminate the values and motivation of anglers and conservationists as well as significant events in the history of angling. It introduces readers to notable British military officers such as George Cartwright and Richard Dashwood, to the operators, guides, and fly-tyers of Newfoundland and Labrador's first tourist lodges, to prominent conservationists such as Lee Wulff, and to the anglers, wardens, and politicians who supported fly-fishing and conservation. Hustins also provides insight into the social conflict generated by conservation regulations modelled on elite angling culture. Accounts of poaching, squatting of fishing holes, and the vandalism of a hatchery reveal that conservation has been divisive and contested throughout Newfoundland and Labrador's history.

Hustins's study contains rich material on the social history of Newfound- 
land and Labrador. Not all fishers and sportswriters were men, and Hustins notes the important contributions women and youth made to the fly-fishing industry. Some of the book's most interesting analysis centres on the local economies, cultures, and traditions that arose around the guiding profession. This includes stories of outfitters who dumped ice into a fishing hole to preserve salmon in a heat wave and discussion of the impact that the introduction of moose to Newfoundland had on fly-tying. Hustins traces the tourist industry's development from the eighteenth- and nineteenth-century vacations of angling military officers to the seasonal holidays of wealthy urbanites, while also noting the emergence of international sporting shows, popular travel, and state-sponsored tourism in the late nineteenth and twentieth centuries. Readers learn about the social and environmental impacts of the steamships, railways, highways, and float planes that carried people to and across Newfoundland and Labrador; the region's portrayal in sporting and natural history literature and wildlife films; and the tourists, promoters, and rural residents who formed the backbone of the tourist economy.

Anglers and scholars from outside Newfoundland and Labrador will also find Rivers of Dreams of interest. It complements studies of angling, wildlife conservation, and sport tourism from across North America, while providing insight into the history of a geographically distinct jurisdiction that did not come under Canadian federal conservation laws until 1949. Hustins highlights the divergence of Newfoundland and Labrador's conservation and angling policies from those in other British North American polities. While provinces such as New Brunswick and Quebec opted to lease fishing rights to wealthy groups of sportsmen and adopted artificial propagation, Newfoundland and Labrador kept its waters open to all fishers and relied on natural spawning.

Atlantic salmon connect the rivers and people of Newfoundland and Labrador to the North Atlantic world and Hustins is attentive to the international regulation of migratory fish and to human impacts on salmon populations. The book contains insights into the limits of British conservation on the French Shore, diffusion of technologies and conservation practices, and the modern policies and international treaties that manage and mismanage species that pass through the nets of several jurisdictions. Hustins concludes his study with an astute appraisal of the success, failure, and potential of salmon conservation, offering suggestions on how policy-makers and the public can work towards improving conservation.

Rivers of Dreams provides readers with far more than a history of angling and conservation. Its treatment of the tourist industry, natural scenery, rural 
communities, and literary sources make it a welcome addition to a scholar's study, rural fishing camp, or urban coffee table. It enriches scholarly and popular literature on Newfoundland and Labrador by providing new perspectives and cases studies on social protest, tourism, and resource regulation. Moreover, its focus on the culture of sport fishing and on anglers' contributions to conservation helps address a gap in the regional and national histories that have been largely more attentive to Newfoundland and Labrador commercial fishers, fish plant workers, merchants, and politicians than sportsmen. In addition, numerous images, including paintings and photographs of anglers and prize catches, quirky tourist ads, and commemorative stamps, enhance the study's value and appeal. The book's layout, however, would have been improved had the large page-length quotations been reduced or moved to the chapter devoted to excerpts of anglers' writings. Rivers of Dreams is a study of angling and conservation and is rooted in sources and perspectives associated with anglers, conservation proponents, and workers in the tourist industry. Although the people at the centre of his study did not always have a nuanced or sympathetic attitude towards those who did not consider fishing a sport, Hustins sought to acknowledge the views and experiences of subsistence and commercial fisherman who were marginalized by conservation measures modelled on what scholars elsewhere have labelled "The Code of the Sport." Rivers of Dreams captures the history and spirit of salmon conservation and angling. Its historical critique of public policy commands attention in today's world of collapsing fish stocks and declining fishing industries.

Jason Hall

University of New Brunswick 